\title{
CHARACTERIZATION AND IDENTIFICATION OF BIOACTIVE COMPOUNDS IN AGRO-FOOD WASTE FLOURS
}

Camila Gonçalves Rodrigues ${ }^{a}$, Viviane Dias Medeiros Silva ${ }^{a}$, Anna Cláudia de Freitas e Loyolaa, Mauro Ramalho Silvaa, Rodinei Augusti ${ }^{b}$, Julio Onesio Ferreira Melo ${ }^{c, *,(\mathbb{D},}$, Lanamar de Almeida Carlos ${ }^{\mathrm{d}}$ e Camila Argenta Fante ${ }^{\mathrm{a}}$

${ }^{a}$ Faculdade de Farmácia, Universidade Federal de Minas Gerais, 31270-901, Belo Horizonte - MG, Brasil

bDepartamento de Química, Instituto de Ciências Exatas, Universidade Federal de Minas Gerais, 31270-901, Belo Horizonte MG, Brasil

'Departamento de Ciências Exatas e Biológicas, Universidade Federal de São João del-Rei, 35702-031 São João del-Rei - MG, Brasil

${ }^{\mathrm{d}}$ Departamento de Engenharia de Alimentos, Universidade Federal de São João del-Rei, 35702-031 São João del-Rei - MG, Brasil

Recebido em 12/09/2021; aceito em 17/11/2021; publicado na web em 17/01/2022

\begin{abstract}
One of the recurrent problems of the agroindustry sector is the incorrect disposal of waste because of the complexity of the material, moisture, among other factors. Waste is not used in tonnage, but is systematically used. Examples of residues are malt bagasse and cassava peel, produced in large quantities in the brewing industry and flour production, respectively. In this context, the objective of this study was to evaluate bioactive compounds of flours produced from agroindustry waste to potentiate their use as an ingredient rich in antioxidants. The flours produced from agroindustry waste were evaluated for phenolic compounds, total carotenoids, antioxidant activity, and the attainment of phenolic profiles and fingerprints by paper spray mass spectrometry. It was possible to identify a broad class of compounds in both flours, such as phenolic acids, flavonoids, among others. The flours can be possibly included in food commodities or packaging formulation since they are natural antioxidants, thus adding value to these products and reducing environmental issues. However, further analysis is needed to ensure bioavailability as well as food safety.
\end{abstract}

Keywords: waste; fragments; phenolics; cassava peel; malt bagasse.

\section{INTRODUCTION}

Waste generation in the agroindustry sector has been a recurring problem that compromises the environment. Tons of plant waste is produced annually by different industrial segments. Due to the large volume generated, transport difficulty, low added value, and high propensity for microbiological growth, these residues are destined mainly for supplementation in animal feed, used as raw material for combustion and/or disposed of in landfills. Their underutilization is due to the difficulty in treating them to be used again by the industry. ${ }^{1}$ The big challenge is to provide alternative, sustainable destinations in quantily for waste. ${ }^{2}$ This amount includes the by-products of the exploitation of starch sources, as well as waste from the brewing industry, which, for having peculiar characteristics, has gained space as the raw material of different commodities, at a time when the appeal for natural products by a large part of the population is increasing. ${ }^{3}$

The progressive increase in production in the brewing industry leads to many residues such as malt bagasse. ${ }^{4}$ Barley malt bagasse is formed after malt germination and mashing, in the must filtration stage, generating 14 to $20 \mathrm{~kg}$ of this residue for every 100 liters of beer produced. ${ }^{5,6}$ The destination of malt bagasse varies according to the region, and it can be directed to several applications: human food, energy production (charcoal, biogas, and direct combustion), incorporation in construction materials, paper production, adsorbents, and mainly for use as animal feed. ${ }^{7,8}$

Studies conducted by the Brazilian Institute of Geography and Statistics highlighted that in 2019 the Brazilian cassava production reached 18.9 million tons, and $60 \%$ of the harvested roots are used in flour production with a high residue generation. ${ }^{9,10}$ During the various processing stages, dry and wet residues are generated, most of which are dried, discarded directly in the soil, or used as animal feed. ${ }^{10}$

*e-mail: onesiomelo@gmail.com
Cassava peel, a material rich in fibers, minerals, and sugars, has been used as animal feed and energy production. ${ }^{11,12}$ Malt bagasse contains proteins and fibers (cellulose, hemicellulose, and lignin) in its composition in addition to extractives and ash in smaller proportions. ${ }^{13}$ The search for bioactive compounds comprises an appealing possibility to aggregate value to these underused residues, some studies report this possibility. ${ }^{14-18}$ Bioactive compounds can promote health benefits due to their antioxidant and antibacterial activities and their capability to stimulate the immune system, among other properties. ${ }^{19}$

High-performance liquid chromatography (HPLC) has been currently used to identify bioactive compounds. ${ }^{20}$ HPLC provides qualitative and quantitative analyses, but with some disadvantages, such as the need for time-consuming sample preparation and chromatographic run steps and high costs. ${ }^{21}$ Recent developments in ambient ionization mass spectrometry may be an alternative to overcome these limitations, especially analysis time and reagents. These techniques have been used to obtain fingerprints of several complex matrices via ultra-fast, low-cost, and clean analyses..$^{22,23}$ Among ambient ionization techniques, paper spray mass spectrometry (PS-MS), developed by Wang et al.,${ }^{24}$ stood out for its remarkable ability to quickly and efficiently generate fingerprints from complex samples. ${ }^{20,25-28}$

The present manuscript aims to analyze, detect and identify bioactive compounds in some agroindustry residues, namely cassava peel, and malt bagasse. The prospect for their possible uses in new market segments, with the consequent reduction of their disposal in nature, is also part of the objectives of this work.

\section{EXPERIMENTAL}

For the production of flours, cassava peel and malt bagasse purchased at the local market in Sete Lagoas, MG, Brazil, between 
May and June 2018 were used as raw materials. For the preparation of the flours, the residues were dried in a cabin dryer with forced air circulation (Sparrow, PE 60 Model, Petrópolis, Brazil) at $70{ }^{\circ} \mathrm{C}$ for 12 hours. The dry material was crushed in a Walita Food Processor $(750 \mathrm{~W})$, with the grinder attachment for 2 minutes at speed 1 (9500 rpm). Cassava peel (CPF) and malt bagasse (MBF) flours were placed in amber glass jars and stored at $-18{ }^{\circ} \mathrm{C}$ (in a freezer) until use, in order to avoid moisture and loss of bioactive compounds. The other reagents used were of analytical grade.

\section{Tannins}

The detection of tannins in the flours was performed according to the vanillin/ $\mathrm{HCl}$ method with absorbance reading in a spectrophotometer (Micronal AJX-1900 model, São Paulo) at 500 nm. ${ }^{29}$ Tannin concentration in the samples was determined by building a standard curve with different catechin concentrations. The absorbance of the sample was replaced in the equation $Y=0.268 x+0.007$, with $R^{2} 0.99$, where $\mathrm{x}$ is tannins concentration expressed in $\mathrm{mg}$ Catechin Eq/g, on dry basis and $\mathrm{Y}$ is the absorbance.

\section{Total Carotenoids}

After extraction with acetone and partition with petroleum ether, the total carotenoids were quantified by spectrophotometry at $450 \mathrm{~nm}$. The total carotenoid $(\mathrm{C})$ content was calculated using the equation $\mathrm{C}=100\left[\left(\mathrm{~A} \times \mathrm{V} \times 10^{-4}\right) /(\mathrm{E} 1 \% \times \mathrm{M})\right]$, where: $\mathrm{A}=$ Absorbance at $450 \mathrm{~nm}$, multiplied by the dilution factor; $\mathrm{V}=$ Sample volume $(25 \mathrm{~mL}) ; \mathrm{E} 1 \%=$ Extinction coefficient of $\beta$-carotene in petroleum ether $=2592, \mathrm{M}=$ Sample mass $(\mathrm{g})$. The results were expressed in $\mathrm{mg}$ of carotenoids per gram of dry basis. ${ }^{30}$

\section{Extraction}

The extraction was done according to Rufino et al. ${ }^{31}$ to evaluate the total phenolic content, antioxidant activity, phenolic profile and to acquire the PS mass spectra. For this, $2.5 \mathrm{~g}$ of sample were weighed, and $10 \mathrm{~mL}$ of methanol/water $(50: 50, \mathrm{v} / \mathrm{v})$ were added to a $50-\mathrm{mL}$ Falcon tube. After $1 \mathrm{~h}$ at room temperature protected from the light, the tubes were centrifuged (Sigma, 2K15, Germany) at $2800 \mathrm{G}$ for $22 \mathrm{~min}$, and the supernatant was recovered. After, $10 \mathrm{~mL}$ of acetone/ water $(70: 30, \mathrm{v} / \mathrm{v})$ were added to the residue, with new incubation and centrifugation under the same conditions described. Both supernatants were mixed, and the volume was completed to $25 \mathrm{~mL}$ with distilled and deionized water.

\section{Total phenolic compounds and antioxidant activity}

The total phenolic compounds of the flours were determined by the Folin-Ciocalteu method according to the methodology of SAHAN, CANSEV, and GULEN. ${ }^{32}$ Antioxidant activity was evaluated by the methods FRAP and ABTS and DPPH according to the official method 2012.04 described by AOAC. ${ }^{31,33}$

\section{Phenolic profile}

The determination of the profile of the main phenolic compounds present in the flours ( $\mathrm{CPF}$ and $\mathrm{MBF}$ ) was performed according to the chromatographic method described by Eça et al. ${ }^{21}$ with some modifications. The extract was filtered with a $0.22 \mu \mathrm{m}$ nylon syringe filter and placed in vials for automatic injection of $1 \mu \mathrm{L}$ in ultra-performance liquid chromatography (Waters, Acquity UPLC ${ }^{\circledR}$ Class, Milford, Massachusetts, USA) equipped with diode-array
UV detector, quaternary pump, online degasser, and automatic sampler. The data were processed using Empower ${ }^{\circledR}$ software. The chromatographic conditions were as follows: Acquity UPLC ${ }^{\circledR}$ BEH C18 column ( 2.1 x $100 \mathrm{~mm} ; 1.7 \mu \mathrm{m}$, Waters, Milford, Massachusetts, USA), a constant flow rate of $0.3 \mathrm{~mL} \cdot \mathrm{min}^{-1}$ with two mobile phases ( $\mathrm{A}=$ acetonitrile and $\mathrm{B}=$ water: formic acid, 99.75:0.25). The standards diluted in water (gallic acid, catechin, and chlorogenic acid) were run for $17 \mathrm{~min}$ in isocratic elution mode of 5:95 v/v (A:B). For the standards diluted in methanol (caffeic acid, ellagic acid, quercetin and rutin), the following elution gradients were applied: from 0 to $8 \mathrm{~min}=8: 92(\mathrm{~A}: \mathrm{B})$; from 8 to $14 \mathrm{~min}=15: 85$; and from 14 to $22 \mathrm{~min}=25: 75$. The spectra were obtained at 253,271,279, 322, and $372 \mathrm{~nm}$. Analytical curves were constructed for each standard within the concentration range from 13.75 to $220 \mathrm{ppm}$, obtaining $\mathrm{R}^{2}$ greater than 0.999 . The results obtained were expressed in $\mu \mathrm{g} \mathrm{g}^{-1}$ of extract.

\section{PS-MS}

The analysis of the chemical profile of the samples was performed using a LCQ Fleet mass spectrometer (ThermoScientific, São José, CA, USA) equipped with a paper spray ionization source. The flour samples were analyzed in positive and negative ionization modes. A triangle-shaped chromatographic paper $(1.5 \mathrm{~cm}$ height and $1.0 \mathrm{~cm}$ width) was cut, held by copper support, and positioned $0.5 \mathrm{~cm}$ away from the mass spectrometer inlet. This system was connected to a high-voltage source from the mass spectrometer via a copper wire. Finally, $2.0 \mu \mathrm{L}$ of the flour extracts were applied to the central part of the triangle, $40.0 \mu \mathrm{L}$ of methanol were transferred to chromatographic paper, and the high-voltage applied. The analyses of each flour were performed in triplicate for the positive and negative ionization modes..$^{20,34,35}$

The following MS conditions were applied: source voltage of $+4.0 \mathrm{kV}$ (positive ionization mode) and $-3.0 \mathrm{kV}$ (negative ionization mode); capillary tension of $40 \mathrm{~V}$; transfer tube temperature of $275^{\circ} \mathrm{C}$; tube lens voltage of $120 \mathrm{~V}$; and mass range of $\mathrm{m} / \mathrm{z}, 100$ to 1000 (positive and negative ionization modes). The ions and their fragments were identified based on data described in the literature. The collision energies used to fragment the compounds ranged from 15 to $40 \mathrm{mu}$ (manufacturer unit).

\section{Statistical analysis}

First, the normality of the results and the homogeneity of variances were evaluated. The mean results of the variables were analyzed by the Student's t-test (for normal distribution) or by the Wilcoxon-Mann-Whitney test (for no normal distribution) with a significance of $5 \%$. All tests were performed with the assistance of the SPSS 15.0 software for Windows (SPSS Inc., USA).

\section{RESULTS AND DISCUSSION}

The contents of condensed tannins (T), total carotenoids (C), and total phenolics $(\mathrm{P})$ are shown in Table 1. Note that the content of these compounds remarkably differed between the flours. The $\mathrm{T}$ content was higher for $\mathrm{CPF}$ than $\mathrm{MBF}$, while an opposite result is observed for $\mathrm{C}$ and $\mathrm{P}$.

Tannins (T) are secondary metabolites of polyphenolic nature, responsible for the characteristics normally attributed to plants that contain high levels of these substances, such as astringency and the ability to precipitate proteins. ${ }^{36}$ The higher T content in CPF, when compared to MBF, is possibly because CPF was obtained directly from washed cassava peel and subjected to the drying process. Although several antinutritional factors are attributed to tannins, 
Table 1. Condensed tannins (T), total carotenoids $(\mathrm{C})$, and total phenolics $(\mathrm{P})$ in cassava peel (CPF) and malt bagasse (MBF) flours on a dry basis

\begin{tabular}{lcc}
\hline Variables under study & $\mathrm{CPF}^{1}$ & $\mathrm{MBF}^{1}$ \\
\hline $\mathrm{T}(\mathrm{mg}$ CAT Eq. $/ 100 \mathrm{~g})$ & $1066.98 \pm 0.06^{\mathrm{a}}$ & $48.67 \pm 0.21^{\mathrm{b}}$ \\
$\mathrm{C}(\mu \mathrm{g}$ carotenoid $/ 100 \mathrm{~g})$ & $161.65 \pm 44.28^{\mathrm{b}}$ & $333.85 \pm 15.24^{\mathrm{a}}$ \\
$\mathrm{P}(\mathrm{mg}$ GA Eq/100g) & $230.83 \pm 37.17^{\mathrm{b}}$ & $549.41 \pm 13.53^{\mathrm{a}}$ \\
\hline
\end{tabular}

${ }^{1}$ Mean value \pm standard deviation. Means followed by equal letters in the same row, for the same parameters, do not differ at 5\% significance level by the Student's t-test.

many studies show the beneficial effects upon ingestion in moderate amounts (10 to $40 \mathrm{~g} / \mathrm{kg}$ of dry matter). They can act as a natural antioxidant, with anticarcinogenic, antihypertensive, and fungicide actions..$^{36-38}$

Carotenoids, in addition to playing a fundamental role in plant metabolism, also have several effects health, such as increased immune response, inhibition of cell proliferation, and reduced risk of degenerative diseases. ${ }^{39,40}$ Gonçalves et al.,${ }^{41}$ found $450 \mu \mathrm{g}$ of carotenoid in $100 \mathrm{~g}$ of fresh white cassava, a value higher than that found in the present study arising from a cassava peel residue (Table 1). MBF (333.85 $\mu \mathrm{g}$ carotenoid/100 g) stood out compared to CPF, which may be related to the presence of other ingredients, in addition to malt, added during beer production. ${ }^{6}$ These residues showed similar carotenoid contents (for $\mathrm{MBF}$ ) when compared to those found for frozen açaí pulp ( 0.21 to $3.84 \mathrm{mg} / 100 \mathrm{~g})$ of different brands in a study conducted by dos Santos et al. ${ }^{42}$ These data once again show the potential for using these residues as a source of bioactive compounds. The $\mathrm{CPF}$ and $\mathrm{MBF}$ flours showed significant levels of total phenolic contents (230.83 and $549.41 \mathrm{mg} \mathrm{GA} \mathrm{Eq} / 100 \mathrm{~g}$ of dry matter, respectively). These results were higher than those found in ripe 'Prata' banana peel (183.85 mg GA Eq/100 g), ${ }^{25}$ thus showing that both residues are potential sources for extracting such compounds. A study conducted with malt bagasse by Da Costa ${ }^{43}$ found $140 \mathrm{mg}$ of $\mathrm{GA} / 100 \mathrm{~g}$ in MBF, lower than the value reported herein (549.41 mg GA Eq/100 g of dry matter), a difference that may be related to the recipe for producing beer in each process. Socaci et al.,${ }^{44}$ found total phenolic contents (determined by the Folin-Ciocalteu method) ranging from $40.97 \mathrm{mg} \mathrm{GA} / 100 \mathrm{~g}$ to $114.23 \mathrm{mg} \mathrm{GA} / 100 \mathrm{~g}$ for malt bagasse, lower than those of the present study.

Regarding the total antioxidant activity determined by the ABTS, FRAP, and DPPH methods (Table 2), the flours showed higher values by the ABST method. There was no significant difference between the CPF and MBF flours (5\% significance) only by the ABTS method. By ABTS and FRAP, the antioxidant activity was higher for MBF, while by DPPH, the highest activity was observed for CPF. These data may indicate that the compounds extracted from MBF probably contain molecules that react with ABTS and FRAP free radicals. Conversely, the CPF extract probably contains more strongly reducing molecules capable of reacting with DPPH free radicals.

Regarding antioxidant activity, the ABTS and DPPH methods were the ones that best suited the studied residues. The samples being tested are better free radical scavengers. There was no significant difference between the residues by the ABTS method, and the values were close to those observed by Loyola et al.,$^{28}$ in flour of green banana peels dried in an oven at $70{ }^{\circ} \mathrm{C}$. Some vegetables analyzed by Tiveron ${ }^{46}$ showed lower values than those found in the residues analyzed here, such as zucchini $\left(12.7 \mu \mathrm{mol} \mathrm{L}^{-1}\right.$ Trolox/g), beetroot (11.1 $\mu \mathrm{mol} \mathrm{L}{ }^{-1}$ Trolox/g), and carrot $\left(8.1 \mu \mathrm{mol} \mathrm{L}^{-1}\right.$ Trolox/g). Hence, the residues (CPF and $\mathrm{MBF}$ ) showed considerable antioxidant activity by the ABTS assay, being even better than some vegetables frequently consumed.

In the method based on the free-radical scavenging principle (DPPH), CPF stood out, but its value was lower than that observed in green banana peels and higher than that found in pineapple residues. $^{28,45}$ (Table 2)

In the phenolic profile (Table 3), gallic acid was found in high amounts in both flours, followed by catechin, rutin, chlorogenic acid, and caffeic acid. Ellagic acid and quercetin were not detected in any of the two flours studied, and in MBF only gallic and caffeic acids were detected. The extraction yield of phenolic compounds correlate with various factors, such as the extraction method and solvent used. ${ }^{47}$ This fact explains why some compounds were not determined by chromatography but were detected by PS-MS.

\section{Full scan PS-MS (fingerprints)}

Figure 1 exemplifies PS-MS spectra of the flours (CPF and MBF) in their positive and negative modes, providing information on the samples' chemical composition. The results reveal the presence of organic acids, phenolic compounds, flavonoids, quinones, triterpenoids, amino acids, sugars, and other ionizable compounds.

\section{Negative mode (-)}

Table 4 displays the possible compounds detected in the negative ionization mode for the CPF and MBF flours: organic acids, phenolic compounds, and flavonoids.

\section{Organic acids}

Cassava peel flour showed more ions classified as organic acids compared to malt bagasse flour. This difference probably occurs because the malt residue goes through more industrial processes than cassava peel, which only goes through the cleaning, sanitizing, and peeling processes. In MBF, octadecanedioic acid $(\mathrm{m} / \mathrm{z}, 313)$ was possibly detected based on the ion of $\mathrm{m} / \mathrm{z}, 295$ arising upon its mass-selection and fragmentation. For $\mathrm{CPF}$, eight organic acids were identified, including some fatty acids and citric acid. The ion of $\mathrm{m} / \mathrm{z}$ 353, with a fragment of $\mathrm{m} / \mathrm{z}, 179$, was identified as chlorogenic acid. Citric $(\mathrm{m} / \mathrm{z}, 191)$ and malic $(\mathrm{m} / \mathrm{z}, 133)$ acids were also observed in the PS(-)-MS, and they have also been found in studies with green and ripe banana peel residue flours..$^{25,28}$

\section{Phenolic Compounds}

The ions of $\mathrm{m} / \mathrm{z}, 170$, with a fragment of $\mathrm{m} / \mathrm{z}, 125$, and $\mathrm{m} / \mathrm{z}, 179$, with a fragment of $m / z 135,{ }^{47}$ correspond to gallic acid and caffeic acid, respectively, were also detected in both flours. In CPF, the following phenolic acids were identified: ellagic acid $(\mathrm{m} / \mathrm{z}, 302$ and

Table 2. Antioxidant activity by ABTS, FRAP, and DPPH methods in CPF and MBF on a dry basis (DB)

\begin{tabular}{|c|c|c|c|c|}
\hline Method & $\mathrm{CPF}^{1}$ & $\mathrm{MBF}^{1}$ & $\begin{array}{l}\text { Green banana peel } \\
\left(\text { Oven } 70^{\circ} \mathrm{C}\right)^{28}\end{array}$ & Pineapple Residue ${ }^{45}$ \\
\hline ABTS $(\mu \mathrm{M}$ Trolox/g) & $26.31 \pm 2.68^{a}$ & $35.73 \pm 13.3^{a}$ & 20.84 & $\mathrm{Nd}$ \\
\hline FRAP ( $\mu$ M ferrous sulfate/g) & $0.02 \pm 0.01^{b}$ & $0.32 \pm 0.12^{\mathrm{a}}$ & $\mathrm{Nd}$ & 72.63 \\
\hline DPPH ( $\mu$ M Trolox/g) & $24.13 \pm 0.73^{\mathrm{a}}$ & $4.32 \pm 0.64^{b}$ & 66.61 & 5.63 \\
\hline
\end{tabular}

${ }^{1}$ Average value \pm standard deviation. Means followed by equal letters in the same row, for the same parameters, do not differ at $5 \%$ significance level by the Student's t-test. 
Table 3. Phenolic profile ( $\mathrm{mg} / 100 \mathrm{~g}$ on dry basis) in cassava peel (CPF) and malt bagasse (MBF) residue flours

\begin{tabular}{lcc}
\hline Phenolics & $\mathrm{CPF}^{1}$ & $\mathrm{MBF}^{1}$ \\
\hline Gallic Acid & $270.62 \pm 1.13^{\mathrm{a}}$ & $134.73 \pm 1.07^{\mathrm{b}}$ \\
Catechin & $14.87 \pm 1.04$ & $\mathrm{ND}$ \\
Chlorogenic Acid & $0.79 \pm 0.42$ & $\mathrm{ND}$ \\
Caffeic Acid & $0.19 \pm 0.26^{\mathrm{a}}$ & $0.03 \pm 0.02^{\mathrm{a}}$ \\
Rutin & $0.96 \pm 0.82$ & $\mathrm{ND}$ \\
Ellagic Acid & $\mathrm{ND}$ & $\mathrm{ND}$ \\
Quercetin & $\mathrm{ND}$ & $\mathrm{ND}$ \\
\hline
\end{tabular}

${ }^{1}$ Average value \pm standard deviation. Means followed by equal letters in the same row, for the same parameters, do not differ at $5 \%$ significance level by the Student's t-test. ND: Not detected.

fragment of $\mathrm{m} / \mathrm{z}, 284)$ and ferulic acid $(\mathrm{m} / \mathrm{z}, 193$ and fragment of $\mathrm{m} / \mathrm{z}$ 134). Note that the chromatographic method used could not detect ellagic acid for this study (Table 3 ).

\section{Flavonoids}

The flavonoid group contains the highest number of substances identified in the negative ionization mode. Flavonoids are secondary metabolites of plants, and their intake is linked to preventive action against chronic non-communicable diseases, with antioxidant, antiinflammatory and anticarcinogenic potential and cardiovascular protection capacity. ${ }^{48} \mathrm{In} \mathrm{MBF}$, the ion of $\mathrm{m} / \mathrm{z} 431$ was identified as vitexin based on its main fragment $(\mathrm{m} / \mathrm{z} 311)$. For CPF, additional flavonoids were identified: catechin $(\mathrm{m} / \mathrm{z}, 289$ and fragment of $\mathrm{m} / \mathrm{z}, 245)$, quercetin $(\mathrm{m} / \mathrm{z}, 301$ and fragment of $\mathrm{m} / \mathrm{z}, 151)$, and rutin $(\mathrm{m} / \mathrm{z}, 609$ and fragment of $\mathrm{m} / \mathrm{z}, 301)$. Flours obtained from green banana peel residue and loquat leaf extract also contained rutin and catechin. ${ }^{28,35}$ Rutin and quercetin have pharmacological properties such as anti-inflammatory action and antioxidant power, acting on free radicals responsible for degenerative diseases and cell aging and death. ${ }^{49}$

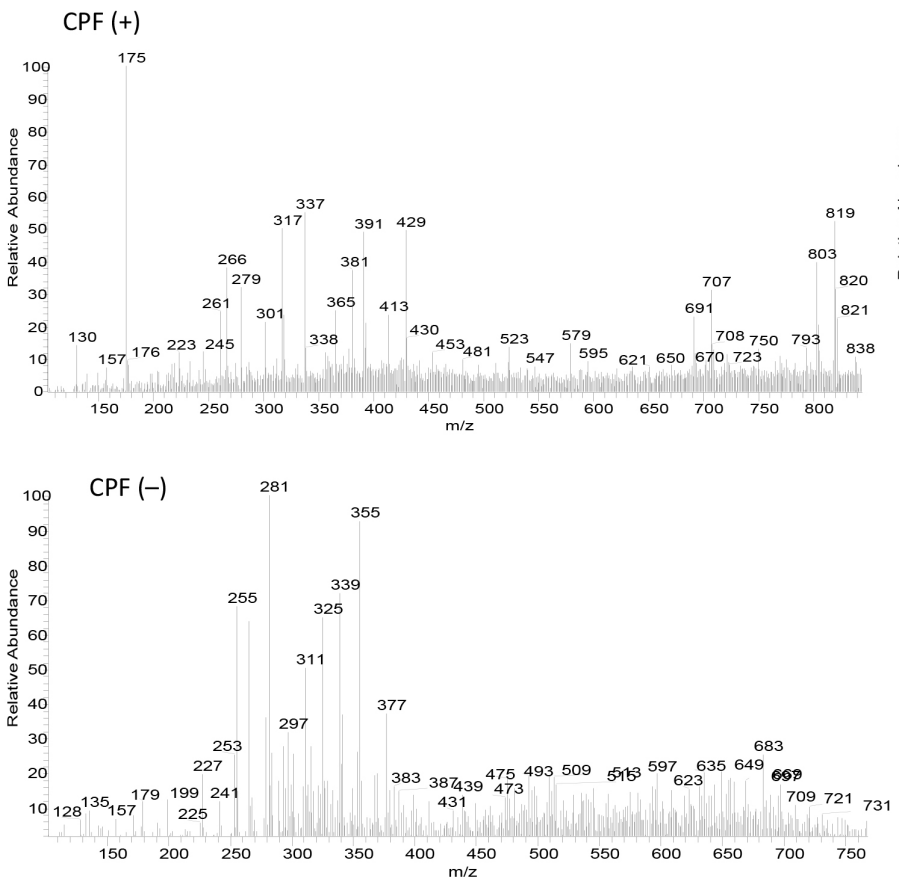

Positive mode (+)

Table 5 presents the possible compounds detected in the positive ionization mode for the $\mathrm{MBF}$ and $\mathrm{CPF}$ flours.

\section{Amino acids}

CPF showed the presence of L-arginine, identified in its protonated form of $m / z, 175$, with a fragment of $m / z, 70 .^{20}$

\section{Flavonoids}

Only CPF showed molecules that could be identified as flavonoids in the positive mode. The ion of $m / z 595$ (fragment of $m / z$ 287) was identified as tiliroside (kaempferol-3-O-(6- $p$-coumaroyl)-glycoside), a glycosidic flavonoid with anti-inflammatory and antioxidant properties. $^{50}$

\section{Sugars}

From the profile of ions displayed in Table 5, the ion of $\mathrm{m} / \mathrm{z}, 381$, observed exclusively in the PS(+)-MS of CPF, was identified as the adduct of potassium of sucrose.

\section{CONCLUSIONS}

Even though they are agro-industrial residues,considered as products of low added value, the two flours evaluated herein (CPF and MBF) showed remarkable antioxidant activities by the ABTS method. In CPF, the obtained values of phenolic acids (gallic acid, chlorogenic acid, caffeic acid, rutin, and catechin) were higher than those found in MBF. The same trend was revealed by PS-MS data, which indicated organic acids, sugar, and phenolic acids, among other compounds, in the composition of such flours. The PS-MS method proved to be a fast and straightforward technique to obtain the fingerprint of such residues, enabling the identification of several compounds confirmed by high-performance liquid chromatography analyses described in the literature. These residues have the potential for application in the food industry, given the presence of bioactive compounds. However, further studies are required regarding the safety and bioavailability of these active compounds found.
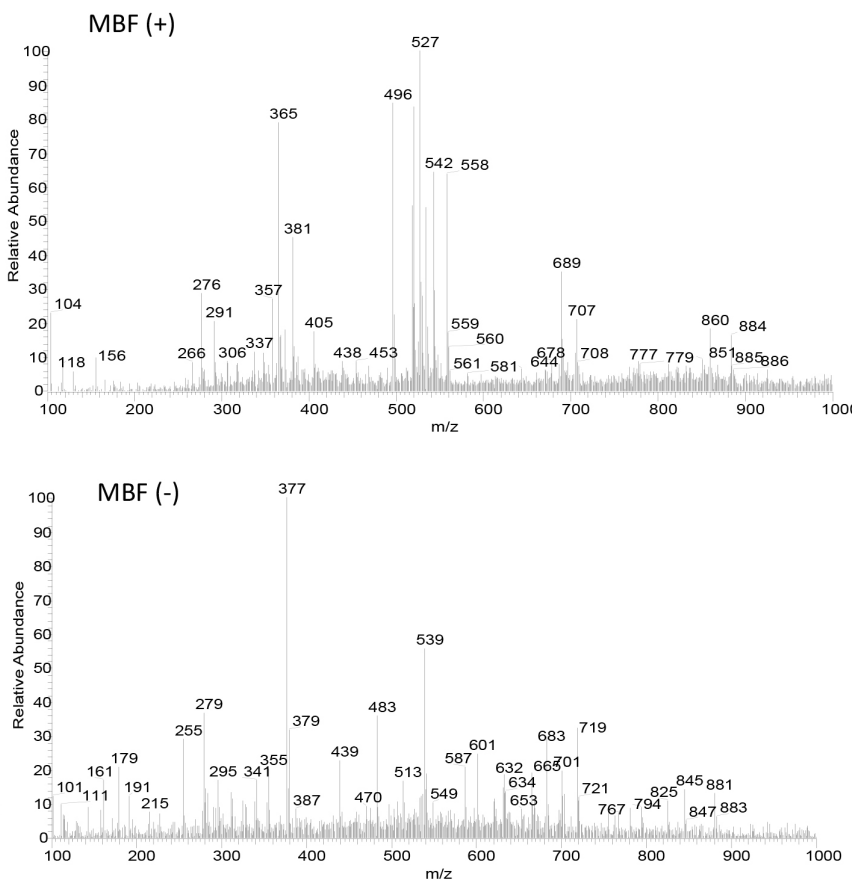

Figure 1. PS-Ms in the positive (+) and negative (-) ion modes 
Table 4. Identification of ions detected in the PS(-)-MS of cassava peel (CPF) and malt bagasse (MBF) flours

\begin{tabular}{|c|c|c|c|c|c|}
\hline \multirow{2}{*}{ Attempted identification } & \multirow{2}{*}{$m / z$} & \multirow{2}{*}{ MS/MS } & \multirow{2}{*}{ Reference } & \multicolumn{2}{|c|}{ Flour } \\
\hline & & & & Cassava & Malt \\
\hline \multicolumn{6}{|c|}{ Organic acids } \\
\hline Malic acid & 133 & 115 & Abu-reidah et $a l^{5} 1$ & + & - \\
\hline Citric acid & 191 & 111 & $\begin{array}{l}\text { Cheikhrouhou and } \\
\text { Khemakhem, }{ }^{52} \text { Silva } \\
\text { et } a l^{2} 0\end{array}$ & + & - \\
\hline Traumatic acid & 227 & 83 & Wang et al. ${ }^{53}$ & + & - \\
\hline Palmitic acid & 255 & 237 & Zhang et al..$^{54}$ & + & - \\
\hline Oleic Acid & 281 & 237 & Wang et al. ${ }^{53}$ & + & - \\
\hline Ricinoleic acid & 297 & 183 & Zhang et al. ${ }^{54}$ & + & - \\
\hline Octadecanedioic acid & 313 & 295 & Zhang et al. ${ }^{54}$ & - & + \\
\hline
\end{tabular}

Phenolic Compounds

\begin{tabular}{|c|c|c|c|c|c|}
\hline \multicolumn{6}{|c|}{$\underline{\text { Benzoic acids }}$} \\
\hline Gallic acid & 170 & 125 & Ee $e t a l^{55}$ & + & + \\
\hline Ellagic acid & 302 & 284 & Ee $e t a l^{55}$ & + & - \\
\hline
\end{tabular}

\begin{tabular}{|c|c|c|c|c|c|}
\hline \multicolumn{6}{|c|}{ Cinnamic acids } \\
\hline Caffeic acid & 179 & 135 & Kang et $a l^{5} 6$ & + & + \\
\hline Ferulic Acid & 193 & 134 & Zhang et al. ${ }^{49}$ & + & - \\
\hline 1-O-Dihydrocaffeoylglycerol & 255 & 135,181 & Kang et $a l^{5} 6$ & + & - \\
\hline Caffeic acid hexose & 341 & 179 & Kang et al. ${ }^{56}$ & - & + \\
\hline Ferulic acid glucoside & 355 & 193 & Svarc-gaj ${ }^{i 57}$ & + & - \\
\hline Hydroxycinnamic acid derivative & 379 & 185 & Valérie et $a l .{ }^{58}$ & - & + \\
\hline Coumaric acid derivative & 487 & 145 & Laura M. et al ${ }^{59}$ & + & - \\
\hline Chlorogenic acid & 353 & 179 & $\begin{array}{c}\text { Ammerer, Arle and } \\
\text { Chieber }^{60}\end{array}$ & + & - \\
\hline
\end{tabular}

\begin{tabular}{|c|c|c|c|c|c|}
\hline \multicolumn{6}{|c|}{ Quinones } \\
\hline Spinochrome A & 265 & 235 & Abu-reidah et al. ${ }^{51}$ & + & - \\
\hline \multicolumn{6}{|c|}{ Flavonoids } \\
\hline Catechin & 289 & 245 & Valls et al..$^{61}$ & + & - \\
\hline Quercetin & 301 & 151,178 & Wang et al..$^{53}$ & + & - \\
\hline Epigallocatechin & 305 & 261,287 & Valls et al. ${ }^{61}$ & + & - \\
\hline Vitexin & 431 & 311 & Simirgiotis et al. ${ }^{62}$ & - & + \\
\hline Apigenin-7-O-glucoside & 431 & 269 & Svarc-gaji57 & - & + \\
\hline Apigenin-6-C-glucoside & 431 & $269,311,341$ & Kang et al..$^{56}$ & - & + \\
\hline 9,10-Dihydro-10-(4-hydroxyphenyl)pyrano[2,3-h]epicatechin-8-on & 435 & 189,341 & Zhang et $a l . .^{54}$ & - & + \\
\hline Dihydrokaempferol hexoside & 449 & 243,405 & Kang et $a l^{5} 6$ & + & - \\
\hline Procyanidin B & 577 & $451,425,407,289$ & Svarc-gajis7 & + & - \\
\hline Rutin & 609 & 301 & Valérie $e t a l^{5} 8$ & + & - \\
\hline $\begin{array}{l}\text { Apigenin-5-O- } \beta \text {-D-glucopyranosyl, 8-C-(6" acetyl)- } \beta \text {-D- } \\
\text { glucopyranoside }\end{array}$ & 635 & 473 & Simirgiotis et al.62 & + & - \\
\hline
\end{tabular}

glucopyranoside

\section{Triterpenoids}

\begin{tabular}{lcccc}
\hline Asiatic acid & 487 & 469 & Zhang et al. $^{54}$ \\
\hline 9-Hode & Other & & \\
\hline
\end{tabular}

Legend: + found, - not found. 
Table 5. Identification of ions detected in the PS(+)-MS of cassava peel (CPF) and malt bagasse (MBF) flours

\begin{tabular}{|c|c|c|c|c|c|}
\hline \multirow{2}{*}{ Attempted identification } & \multirow{2}{*}{$m / z$} & \multirow{2}{*}{ MS/MS } & \multirow{2}{*}{ Reference } & \multicolumn{2}{|c|}{ Flour } \\
\hline & & & & Cassava & Malt \\
\hline \multicolumn{6}{|c|}{ Amino acids } \\
\hline L-Arginine & 175 & 70 & Silva et al..$^{20}$ & + & - \\
\hline \multicolumn{6}{|c|}{ Phenolic Compounds (benzoic acid) } \\
\hline Galloyl pyrogallol & 279 & 153 & Abu-reidah et al. ${ }^{51}$ & + & - \\
\hline \multicolumn{6}{|c|}{ Flavonoids } \\
\hline Diosmetin & 301 & $258 ; 286$ & Zhang et al. ${ }^{54}$ & + & - \\
\hline Myricetin 3-O-galactoside & 481 & 319 & Lin and Harnly ${ }^{63}$ & + & - \\
\hline Chrysoeriol-hexose & 579 & 301 & Abu-reidah et al. ${ }^{51}$ & + & - \\
\hline malvidin 3-(malonoyl)glucoside pelargonidin 3-rutinoside & 579 & 433 & $\mathrm{Rio}^{\mathrm{r}} 4$ & + & - \\
\hline cyanidin 3-rutinoside & 595 & 287 & $\mathrm{Rio}^{\mathrm{r} 6} 4$ & + & - \\
\hline Kaempferol rutinoside & 595 & 287 & Abu-reidah et al. $^{51}$ & + & - \\
\hline Pelargonidin-3-O-(6caffeoyl-glucoside) & 595 & 433,313 & Wang et al..$^{53}$ & + & - \\
\hline Tiliroside & 595 & 287 & Zhang et $a l . .^{54}$ & + & - \\
\hline \multicolumn{6}{|c|}{ Sugars } \\
\hline Sucrose & 381 & 201,219 & Silva et al. ${ }^{20}$ & + & - \\
\hline \multicolumn{6}{|c|}{ Other } \\
\hline Dihydroisovaltrate & 424 & 281,365 & Abu-reidah et al. ${ }^{51}$ & - & + \\
\hline Verbonol & 453 & 435 & Abu-reidah et al. ${ }^{51}$ & + & - \\
\hline Sespendole & 520 & 184 & Abu-reidah et al. ${ }^{51}$ & - & + \\
\hline
\end{tabular}

Legend: + found, - not found.

\section{REFERENCES:}

1. Franca, A. S.; Oliveira, L. S.; Nova Science Publishers 2009, 8, 155.

2. Mirabella, N.; Castellani, V.; Sala, S.; J. Cleaner Prod. 2014, 65, 28.

3. Ayala-Zavala, J. F.; Vega-Veja; Dominguez, C. R.; Palafox, H.; Food Res. Int. 2011, 44, 1866.

4. http://www.mdic.gov.br/comercio-exterior/estatisticas-de-comercioexterior/comex-vis/frame-ppe?ppe $=3108$, accessed in june 2020 .

5. Santos, M. S.; Ribeiro, F. M.; Cervejas e Refrigerantes, São Paulo: CETESB, 2005, p. 58.

6. Verde, A. A.; Cucolo, M. C.; Oliveira, M. L. C.; Cvalieri, F. L. B.; Andreazzi, M. A.; Emanuelli, I. P.; Revista Valore 2019, 4, 84.

7. Mussato, S. I.; Dragone, G.; Roberto, I. C.; J. Cereal Sci. 2006, 43, 1.

8. Carvalho,S.; Frasson, M. F.; Simões, F. S. B.; Bernardes, G. M. C.; Simões, R. R.; Griebler, L.; Pellegrin, A. C. R. S.; Menegon, A. M.; Deponti, L. S.; Severo, M. M.; Mello, V. L.; Arquivo Brasileiro de Medicina Veterinária e Zootecnia 2017, 69, 742.

9. https://sidra.ibge.gov.br/home/lspa/brasil, accessed in January 2022.

10. Bianchi, V. L. D.; Cereda, M. P.; Energia na Agricultura 1999, 14, 34.

11. Dourado, D. P.; Macedo, D. A.; Tonani, F. L. E.; Muraishi, C. T.; Revista Integralização Universitária 2017, 12, 22.

12. Loureiro, A. C.; Soares, J. V. S.; Chaar, J. S.; Hidalgo, A. F.; Souza, L. S. S.; Pereira, A. M.; Appl. Sci. Rev. 2020, 4, 606.

13. Saraiva, B. R..; Vital, A. C. P.; Anjo, F. A.; Cesaro, E.; Matumoto-Pintro, P. T.; Pubsaúde 2018, 1, a009.

14. Mohd-Asharuddin, S.; Othman, N.; Zin, N. S. M.; Tajarudin, H. A.; MATEC Web of Conferences, EDP Sciences, 2017, 06012.

15. da Rosa Almeida, A.; Geraldo, M. R. F.; Ribeiro, L. F.; Silva, M. V.; Maciel, M. V. D. O. B.; Haminiuk, C. W. I.; Acta Scientiarum. Technol. 2017, 39, 269

16. Fărcaş, A. C.; Socaci, S. A.; Mudura, E.; Dulf, F. V.; Vodnar, D. C.; Tofană, M.; Salanță, L. C.; Brew. Technol. (2017), doi: 10.5772/ intechopen.69231.
17. Souto, L. R. F.; Caliari, M.; Soares, M. S.; Fiorda, F. A.; Garcia, M. C.; Food Sci.Technol. 2016, 37, 19.

18. Júnior, L. F. C.; Valente, G. D. F. S.; Silva, M. D. M. C.; Brazilian Journal of Development 2020, 6, 74010.

19. Moraes, F. P.; Rev. Eletronica Farm. 2007, 3, 109.

20. Silva, M.; Freitas, L.; Souza, A.; Araújo, R.; Lacerda, I.; Pereira, H.; Augusti, R.; Melo, J.; J. Braz. Chem. Soc. 2019, 30, 1034.

21. Eça, K. S.; Machado, M. T. C.; Hubinger, M. D.; Menegalli, F. C.; J. Food Sci. 2015, 80, C2389.

22. Zhi-Ping, Z.; Xiao-Ning, L.; Ya-Jun, Z.; Chin. J.; Anal. Chem. 2014, 42, 145.

23. Guo, Y.; Gu, Z.; Liu, X.; Liu, J.; Ma, M.; Chen, B.; Wang, L.; Phytochem. Anal. 2017, 28, 344.

24. Wang, H.; Liu, J.; Cooks, R. G.; Ouyang, Z.; Angew. Chem., Int. Ed. 2010, 122, 889 .

25. Silva, V. D. M.; Arquelau, P. B. F.; Silva, M. R.; Augusti, R.; Melo, J. O. F.; Fante, C. A.; Quim. Nova 2020, 43, 579.

26. Silva, V. D. M.; Macedo, M. C. C.; Santos, A. N.; Silva, M. R.; Augusti, R.; Lacerda, I. C. A.; Melo, J. O. F.; Fante, C. A.; Rapid Commun. Mass Spectrom. 2020b, 34, 8883.

27. Minighin, E. C.; Anastácio, L. R.; Melo, J. O. F.; Labanca, R. A.; Res. Society Develop. 2020, 9, e760986116.

28. e Loyola, A. C. F.; Silva, V. D.; Silva, M. R.; Rodrigues, C. G.; Dos Santos, A. N.; Melo, J. O.; Fante, C. A.; J. Braz. Chem. Soc. 2021, 32, 953.

29. Price, M. L.; Hagerman, A. E.; J. Agric. Food Chem. 1980, 28, 459.

30. Rodriguez-Amaya D. B.; J. Food Compos. Anal. 1996, 196.

31. Rufino, M. S. M.; Alves, R. E.; Brito, E. S.; Pérez-Jiménez, J.; SauraCalixto, F.; Filho, J. M.; Food Chem. 2010, 121, 996.

32. Sahan, Y.; Cansev, A.; Gulen, H.; Food Sci. Biotechnol. 2013, 22, 613.

33. AOAC. Association of Official Analytical Chemists. Official methods of analysis of the Association of Official Analytical Chemists, $19^{\text {th }} \mathrm{ed} .$, Ed. William Horwitz: Gaithersburg, 2012. 
34. Campelo, F. A.; Henriques, G. S.; Simeone, M. L. F.; Queiroz, V. A. V.; Silva, M. R.; Augusti, R.; Melo, J. O. F.; Lacerda, I. C. A.; Araujo, R. L. B.; J. Braz. Chem. Soc. 2020, 31, 788.

35. Silva, E. B. M.; Augusti, R.; Melo, J. O. F.; Takahashi, J. A.; Araújo, R. L. B.; Quim. Nova 2020, 43, 319.

36. Haslam, E.; J. Nat. Prod. 1996, 59, 205.

37. Brandes.; Feitas, E. A. G.; Agropecuária Catarinense 1992, 5, 44.

38. De Angelis, R. C.; Importância de alimentos vegetais na proteção da saúde: fisiologia da nutrição protetora e preventiva de enfermidades degenerativas, Atheneu: São Paulo, 2001, p. 295.

39. Sentanin, M. A.; Amaya, D. B. R.; Food Sci. Technol. 2007, 27, 13.

40. Murillo, E.; Giuffrida, D.; Menchaca, D.; Dugo, P.; Torre, G.; MeléndezMartinez, A. J.; Mondello, L.; Food Chem. 2013, 140, 825.

41. Gonçalves Silva, R. M.; Figueiredo, P. A.; Peixoto, E. C. T.; De M.; Silva, L. P.; Biosci. J. 2013, 30, 556.

42. Dos Santos, G. M.; Maia, G. A.; Souza, P. H. M.; Costa, J. M. C.; Figueiredo, R. W.; Prado, G. M.; Arch. Latinoam. Nutr. 2008, 58, 187.

43. Da Costa, G. M.; Silva, V. R. O.; Louzada, M. H.; Queiroz, I. C.; Ciên. Tecnol. Meio Ambiente 2020, 1, 11.

44. Socaci, S. A.; Fărcaş, A. C.; Diaconeasa, Z. M.; Dan Vodnar, D. C.; Rusu, B.; Tofană, M.; J. Cereal Sci. 2018, 80, 180.

45. Infante, J.; Selani, M. M.; Toledo, N. M. V.; Silveira-Diniz, M. F.; Alencar, S. M.; Spoto, M. H. F.; Braz. J. Food Nutr. 2013, 24, 87.

46. Tiveron, A. P.; Tese de Doutorado, Universidade Federal de São Paulo, Brasil, 2010.

47. Chirinos, R.; Pedresch, R.; Rogez, H.; Larondelle, Y.; Campos, D.; Ind. Crops Prod. 2013, 47, 145.

48. Queiroz, V. A. V.; Moraes, E. M.; Schaffert, R. E.; Moreira, A. V.; Ribeiro, S. M. R.; Martino, H. S. D.; Rev. Bras. Milho Sorgo 2011, 10, 180.

49. Famacognosia: da planta ao medicamento; Simões, C. M. O., org.; $6^{\text {th }}$ ed., Editora da UFSC e UFRGS: Porto Alegre, 2007.
50. Sala, A.; Recio, M. C.; Giner, R.M.; Manez, S.; Tournier, H.; Schinella, G.; Rios, J. L., J. Pharm. Pharmacol. 2002, 54, 365.

51. Abu-Reidah, I. M.; Ali-Shtayeh, M. S.; Jamous, R. A.; ArráezRomán, D.; Segura-Carretero, A.; Food Chem. 2015, 166, 179.

52. Abid, M.; Yaich, H.; Cheikhrouhou, S.; Khemakhem, I.; Bouaziz, H. A.; Ayadi, M. A.; J. Food Sci Technol. 2017, 54, 2890.

53. Wang, J.; Jia, Z.; Zhang, Z.; Wang, Y.; Liu, X.; Wang, L.; Lin, R.; Molecules 2017, 22, 476.

54. Zhang, L.; Zhu, M. T.; Shi, T.; Guo, C.; Huang, Y. S.; Chen, Y.; Xie, M. Y.; Food Funct. 2017, 8, 341.

55. Lee, J. H.; Johnson, J. V.; Talcott, S. T.; J. Agric. Food Chem. 2005, 53, 6003.

56. Kang, J.; Price, W. E., Ashton, J.; Tapsell, L. C.; Johnson, S.; Food Chem. 2016, 211, 215.

57. Cvetanovic, A.; Svarc-Gaji, J.; Maskovic, P.; Savic, S.; Nikolic, L.; Ind. Crops Prod. 2015, 65, 582.

58. Tsamo, C. V. P.; Herent, M.; Tomekpe, K.; Emaga, T. H.; QuetinLeclerq, J.; Rogez, H.; Larondelle, Y.; Andre, C.; Food Chem. 2015, 167, 197.

59. Bystrom, L. M.; Lewis, B. A.; Brown, D. L.; Rodriguez, E.; Obendorf, R. L.; Food Chem. 2011, 111, 1017.

60. Schütz, K.; Kammerer, D.; Carle, R.; Schieber, A.; J. Agric. Food Chem. 2004, 52, 4090.

61. Valls, J.; Millán, S.; Martí, M. P.; Borràs, E.; Arola, L.; J. Chromatogr. A 2009, 1216, 7143 .

62. Simirgiotis, M. J.; Schmeda-Hirschmann, G.; Bórquez, J.; Kennelly, E. J.; Molecules 2013, 18, 1672.

63. De Brito, E. S.; De Araújo, M. C. P.; Lin, L. Z.; Harnly, J.; Food Chem. 2007, 105, 1112.

64. Wu, X.; Prior, R. L.; J. Agric. Food Chem. 2005, 53, 2589. 